it is argued that there may be a decrease of renin and hence aldosterone production during weightlessness with a consequent loss of sodium in the urine.

Turning to the control and regulation of organ circulation, there are brief reviews of the relevant aspects of the cerebral and coronary circulations. Both these reviews are ill balanced in contrast with a well written section on the pulmonary eirculation and the distribution of blood and gas in the lungs. The effect of decreased renal sympathetic nerve activity induced by weightlessness on the renal circulation is discussed. There is also a short clear sumunary of the relevant physiology of the circulation through skin and muscle.

There is a relatively large section on the measurement of blood volume and red coll mass. The factors regulating both these variables are discussed, with emphasis on those which nay be changed in space flight such as weightlessness and a raised inspired oxygen tension.

The third part of the report discusses the principal stress factors associated with prolonged space flight (illustrated by a flight to Mars) that are likely to influence the cardiovascular system. This section includes brief summaries of the physics and physiology of acceleration, vibration, weightlessness, radiation and the composition of the gascous atmosphere. Most of these subjects are dealt with in a superficial manner.

Many of the predictions made by this group with regard to the effects of space flight on the cardiovascular system have been substantiated in the subsequent US Manned Space Flight Programme. In general, however, there is an uneven treatment of the various aspects of this subject in this book.

J. Ernsting

\section{FOREST OBSERVED}

\section{The New Forest}

An Ecological History. By Colin R. Tubbs. Pp. $248+21$ photographs. (David and Charles: Nowton Abbot, May 1969.) 50s.

THE appearance of an ecological history of the New Forest is particularly welcomo. The New Forest itself is a fascinating area -with its peculiar institutions and agriculture, its outstanding biological interest and its ease of access-but, as this book points out, tho arca has escaped the close attention of more than a few historians and field scientists. 'This ecological history presents for the first time, therefore, a concise but thorough account of the physical background to the New Forest and of the effects that man has had on the forest by tho forms of agriculture practised, by his methods of administration and, not least, by his institutions. These effects are traced in relation to both the flora and the fauna, and a very brief glimpse into the future is attempted. Nobody with any intorest in the New Forest, professional or recreational, can afford not to read this book-most will want to have it on their bookshelves.

Considering the very great amount of information that has becn packed into a volume with just under 250 pages, the style is clear and easy to read. There are some minor irritations, such as a curious insistence on insorting the Latin names for various trce species when the common name has already been qualified in this way several times, and even when there could hardly be any doubt as to which species was intended. The reproduction of the photographs is also rather disappointing, many of them appearing rathor flat and toneless.

My most serious criticism of the book, however, is the almost complete absence of any discussion of the ecology of the coniferous species that have been planted in the cnclosures. 'There aro pages of discussion of the ecological significance of the open "natural" forest-the quotes are mine--but very little about the ecology of the extensive areas of coniferous plantations that have been established by the Forestry Commission, as if these areas were lost to the real New Forest. To anyone who has worked or played in the New Forest, this is patently untrue. The coniferous plantations have introduced a rich diversity to the landscape and to the ecology of the district. The arguments used by British ecologists run very close to "broadleaves good, conifers bad", and this book left me with that impression by its almost complete concentration on the ecology of the broadleaved forest.

The publication of this volume raises the question of why more ecological histories of areas of particular interest have not appeared. Admittedly, there are probably few arcas for which tho approach adopted would be quite so revealing, but the objective of an ecological history would often be more rewarding than the studies of the interaction of minor species which are more usually undertaken by ecologists, and it is to be hoped that other ccologists will be stimulated by this book to attempt similar projects.

J. N. R. JEFEERS

\section{LOWEST COMMON DENOMINATORS}

\section{The Nuclear Structures of Protocaryotic Organisms} (Bacteria and Cyanophyceae)

By Wolfgang G. Fuhs. (Protoplasmatologia: Handbuch der Protoplasmaforschung, Band 5/4.) Pp. iv +186 . (Springer-Vorlag: Wion and Now York, 1969.) $83 \mathrm{DM}$; $\$ 20.75$.

'l'eus is in most respects an excellent little book. It has its faults but these are far outweighed by its virtues. 'The accounts of the nucleus in the introductory chapters of general textbooks are usually right up to date; in fact much too up to date, because they adopt the views and retail the information of the most recent workers in the ficld, and ignore overything else: A few years ago, the seeker after information would have been given to understund that true mitosis had been demonstrated to exist in bacteria and tho illustrations were there to prove it. More recently, the impression would be received that nothing was known of the bacterial nucleus, its structure or its behaviour, until the invention of the ultramicrotome. Dr Fuhs does not take such a tone. Starting as an expert, rather on Cyanophyceae than on bacteria, he has made an impressive offort to absorb and digest the great mass of work published in this field over the past thirty years and more, and he points out, in as many words, that it is foolish to try and interpret information from one source while neglecting all others.

These are his virtues, but the first thing that strikes one about the book is not a virtue, although it is a matter of opinion how big a defect it may be: I find the author's argument that the nuclei of bacteria and Cyanophycede are identical quite unconvineing. I admit that "recently acquired knowledge emphasizes the similarity (probable identity) of the basic organizational status of the nuclear material", as Fuhs rather laboriously puts it, but this does not mean that the concept of protocaryosis (or being alike because you both have a simple nucleus) is the more likely to bo valid, but rather tho reverse. It would seem at least equally probable that the resem. blance between the nuclei of these two types of microorganism is a question of lowest common denominator. It may bo that bacteria havo no nuclear membrane, but the nucleus and the flagellar bases are most certainly associated very intimately with the inner layer of the multiple membranes with which the cell is provided. This has not been shown to be true of Cyanophyceae, and it seerns, perhaps, that a working definition of the nuclear mombrane should be agreed, before such weight is placed on the question of its existence. In any case, negative taxonomic criteria are always to be abhorred. 